\title{
Implementation of Covid-19 Handling Policy in the Regional Village of Selakau District, Sambas Regency, West Kalimantan
}

\author{
Rusdiono Pardi * \\ Public Administration, Faculty of Social and Political Science, University of Tanjungpura Pontianak \\ Corresponding email address: pardi@fisip.untan.ac.id
}

\begin{abstract}
This research is motivated by the existence of a policy issued by the government, namely Permendes No. 6 of 2020 concerning Priority for the Use of Village Funds. This study aims to determine the factors that affect the success of handling Covid-19 in Selakau District. This type of research is qualitative research. The results showed that 1) Communication and coordination between implementing actors was carried out well, namely an understanding of the tasks carried out between agencies in handling Covid-19 which resulted in extraordinary synergy in the success of handling Covid-19. 2) The attitude of the implementers shown by the actors / implementers in handling Covid-19 was very good in responding to various policies set by the government. With the attitude of the implementers, it gives public confidence in the implementation of the Covid-19 prevention policy. 3). Human resource support was demonstrated by the formation of Task Force Teams at the Village and Subdistrict Levels. In terms of financial resources, the government has issued various regulations to be able to support the success of this program including Permendes No. 11 of 2019 concerning Priority for the Use of Village Funds which provides opportunities for village governments to use Village Funds for BLT in handling Covid-19 4) The bureaucratic structure implemented in handling covid-19 takes an open bureaucratic structure model, meaning that this model provides opportunities wide for all parties to be involved in the formulation of goals and there is space in forming new institutions, new models or strategies that are more locally oriented, such as developing a solution system a problem based on the participation of all elements, so that there are wider opportunities for involvement bottom-up and top-down balanced.
\end{abstract}

Keywords: Implementation, Policy, Village Fund BLT, Covid-19

DOI: $10.7176 / \mathrm{PPAR} / 11-5-04$

Publication date:June $30^{\text {th }} 2021$

\section{Introduction}

Along with efforts to overcome the epidemic of the impact of Covid-19 and the policies taken, Secretary of the Coordinating Ministry for Economic Affairs Susiwijono "the government has rolled out BLT for affected community groups, especially urban informal sector workers who own stalls, small shops, market traders to increase purchasing power. affected groups, the central government is also coordinating with local governments to obtain data on these informal workers. Next is the online transportation business actor. We have invited Gojek and Grab discussions and have asked for data and some with other online transportation and other daily informal workers. In addition, the government is collaborating with Mall management associations such as the Indonesian shopping centre management association (APPBI) to ask for data on daily workers in shopping centres and daily workers in malls will also get BLT from the government in order to increase purchasing power. (Mutia Fauzia. Kompas.Com. 26 March 2020).

Providing incentives in the form of BLT for informal sector workers as well as daily workers and small business actors. Through this BLT, it is hoped that the public can be disciplined in following government guidelines in dealing with the Covid-19 pandemic, especially those who work in the informal sector. The minister said, "it can help to be able to follow directions and guidelines to reduce interactions and activities and not do gatherings so as to combat the spread of this virus, but still get staples, especially for daily workers. Apart from the government, it can also maintain the level of public consumption amidst the economic downturn due to the coronavirus (covid-19). In addition, the government is also preparing incentives for people affected by layoffs due to Covid-19. The incentives are in the form of compensation and training provided by BPJS of Employment (Mutia Fauzia. Kompas.Com. 24 March 2020).

The various policies taken by the government related to these impacts include the following: First, regarding $\mathrm{PKH}$, the number of recipient families will be increased from 9.2 million to 10 million beneficiary families, while the amount of benefits will be increased by 25 percent. For example, the component of pregnant women increased from Rp. 2.4 million to Rp. 3 million per year, component of early childhood, Rp. 3 million per year, the disability component is Rp. 2.4 million per year and this policy will be effective starting April 2020.

Second, regarding the basic food cards, the number of recipients will increase and increase from 15.2 million recipients to 20 million beneficiaries and the value will increase by $30 \%$ from Rp. 150,000 to $\mathrm{Rp}$. 200,000 and will be given for 9 months. The third is regarding the Pre-employment Card. The pre-work card budget is increased from Rp. 10 Trillion to Rp. 20 Trillion. The number of beneficiaries is 5.6 million people, especially for informal workers as well as micro and small business actors affected by Covid-19. And the value 
of the benefits is Rp. 650,000-Rp. 1,000,000 per month for the next 4 months. Fourth, regarding electricity tariffs, electricity tariff customers of $450 \mathrm{VA}$, totalling around 24 million customers, will be free for the next 3 months, namely for April, May and June 2020. Meanwhile, for 900 VA customers, the total of around 7 million customers will be 50 percent discount, meaning that it only pays half for the months of April, May and June 2020.Fifth, regarding the anticipation of basic necessities. The government reserves RP. 25 Trillion for the fulfilment of basic needs as well as market operations and logistics. Sixth, regarding the relief of credit payments. For informal workers, be it online motorcycle taxis, taxi drivers, MSME actors, fishermen, with daily income with credit below Rp. 10 billion. OJK has issued a regulation regarding this matter and it will take effect this April. The submission procedure has been established, without having to come to the bank or leasing company, simply via email or digital communication media such as WA (Setkab.go.id. Humas. 31 March 2020).

Then for the regions, the seriousness of the West Kalimantan provincial government in preventing the spread of the corona virus or Covid-19 which was declared a pandemic by WHO with the impact of social distancing and physical distancing policies by issuing SE Number 500/0925 / Ass.2 regarding Distribution of Corporate Social Responsibility (CSR ) Companies in West Kalimantan Province, which are aimed at all companies engaged in the mining, plantation and forestry sectors to distribute CSR assistance to the community, especially in the vicinity and locations of the company's areas, in the form of nine staple foods (groceries) and report per company CSR distribution activities to Governor of West Kalimantan and copied to the agencies that handle it. (kalbar.co.id lens. Headline. 27 March 2020)

Furthermore, "West Kalimantan Provincial Government allocates funds for official travel costs in the regional budget (APBD) to help residents buy rice in the midst of the coronavirus pandemic. Fund of Rp. The 50 billion is a total discount of 40 percent of the cost of official travel within the West Kalimantan Provincial Government. The management and allocation of the 2020 APBD has been optimal and is in accordance with the President's order regarding coping with the impact of Covid-19. Leysandri as Secretary stated that the West Kalimantan Provincial Government has the same understanding with the central government in every policy issued. The Governor's directive to the regional apparatus is clear, according to the President's order, there must be one and the same move, so all state institutions arriving in the regions must be the same lest budget movements cause differences in perception " Previously, the West Kalimantan Provincial Government had also allocated a budget to provide assistance of $20 \mathrm{~kg}$ of rice to 463 thousand poor families due to the impact of Covid-19. According to the Governor, the rice aid will be immediately and gradually given by a number of government officials to include poor people who have not been registered (CNN Indonesia. 3 April 2020).

The Head of the Sambas District Health Office, who is also a spokesperson for the Covid-19 Task Force, Dr. Fatah Maryunani revealed that currently the number of people under monitoring (ODP) in Sambas district has increased. Until yesterday (21/4) 17.00. The number of ODP in Sambas district increased from 482 ODP people at the latest data to 495 ODP people, while for PDP in Sambas Regency it was still the same as the previous day, the number was 10 people. (Tribun Pontianak.co.id. 22 April 2020).

Of the number of villages in Selakau District, along with government policies in preventing Covid 19 in the villages, they have formed the Covid-19 Response Village. This, followed up by the formation of village volunteers to prevent Covid-19, is an important step in preventing the spread of Covid-19 or the coronavirus. Because the actions taken will be more measured so that it is more optimal to protect villagers from the spread of Covid-19. The formation of the Covid 19 Response Village will encourage all villages to form village volunteers. Because if it has been established, it will facilitate the process of changing the village fund budget, where the physical development budget can be cancelled or transferred to the budget for handling the Covid-19 outbreak.

To overcome the impact of Covid-19, Mendes PDTT has issued Permendes Number 6 of 2020 as an amendment to Permendes No. 11 of 2019. This Permendes confirms that village funds can be used for BLT Village Funds. BLT sourced from village funds intended for poor communities in villages in the midst of the Coronavirus outbreak. Based on the Permendes, researchers are interested in examining what factors affect the successful implementation of Village Fund BLT for handling Covid-19 in villages in Selakau District, West Kalimantan.

\section{Literature Review}

Public Policies(Public Policy), according to some experts, among others: Lasswell and Kaplan gave meaning to the policy as follows; "A projected program of goals, values and practices" ("a program to achieve goals, values and directed practices"). Public policy is an interconnected process between the formulation of policies (policy formulation), policy implementation (policy implementation) to the assessment (policy evaluation). Formulation of policy or the policy-making(policymaking)in essence are closely related to the decision-making process(decision making). The decision is a choice of various kinds of alternatives (Dill, 1972). Any policy (policy) chosen by the government to do or not to do (Dye, 1978). Nigro (1980) does not differentiate between decision making and policy making, because every policy making is a decision. 
Policy implementation is an action to implement a policy after a program has been formulated or declared to have been in effect (usually in the form of laws, government regulations, judicial decisions, executive orders or presidential decrees). Most of the program or policy implementation process, very much depends on the bureaucratic process. In addition, program or policy implementation also involves a number of interactions and relationships between agencies involved in the implementation process (Ripley and Franklin, 1982: 42).

The implementation of policies in the context of management is within the framework of the bureaucracy and then compiles a program to implement the predetermined policies. Dwiyanto (1995: 2) argues that the success of the bureaucracy in carrying out its function as an implementer is required to increase the effectiveness and efficiency of its performance as well as an attitude of responsiveness, responsibility and accountability. The performance of the bureaucracy involves an essential problem, namely the degree of accomplishment which is very useful for seeing or assessing the quantity, quality and efficiency of services to the community (Keban, 2004: 108).

According to Nugroho (2008: 521-523), there are four points that need to be met in the effectiveness of implementing the stated policy. First is the accuracy of the policy itself, second is the accuracy of the implementation, the third is right on target, and the fourth is the accuracy of the environment. These four points still need to be supported by three supports, namely political support, strategic support and technical support.

The next model is the implementation of public policies which can also be seen from several perspectives or approaches. One of them is the implementation problems approach introduced by Edward III (1980: 9). Edward III proposes an approach to implementation problems by first posing two main questions: "What are the preconditions for successful policy implementation, what are the primary obstacles to successful policy implementation". (what factors support the successful implementation of policies, and what factors hinder the success of policy implementation).

Based on these two questions, four factors are formulated that affect the success of policy implementation, namely communication, resources, disposition or attitude of the bureaucracy / implementer and organizational structure, including the bureaucratic work flow. These four factors are important criteria in implementing a policy.

In this study, the policy implementation model presented by George Edward III is known as $A$ Model of the Policy Implementation. which is used in analysing what factors influence the successful implementation of BLT Village Funds for handling Covid-19 in Villages in Selakau District, West Kalimantan.

\section{Methods}

Methods and approaches used in the research on the prevention of Covid-19 in Selakau Subdistrict Village used a qualitative approach. The focus of the research is Selakau District, with the reason that the location selection is unique because it is located directly adjacent to the City of Singkawang which has quite a high number of Covid19 cases. When the research was carried out for 6 months, starting from April to October 2020. The subjects in this study were actors related to the control of Covid-19 in Selakau District, namely: the Head of the Sub-District Head of the Covid-19 Control Task Force Team, Kapolsek, Danramil. , Head of Puskesmas, Head of Village, Village apparatus Head of BPD, members of BPD, District Facilitator, Village Facilitator, Volunteer Team, Kadus, Head of RT or who understands and knows about covid-19 prevention programs or activities in villages in the Selakau sub-district area, especially Semelagi Besar Village and Sungai Daun Village. In this research, the key instrument is the researcher himself. Meanwhile, to obtain data, researchers used tools, namely: interview guides; observation guidelines; and documentation tools. In this study, testing the credibility of the research data was carried out by means of triangulation. There are three forms of triangulation (Sugiyono, 2005), namely the triangulation of techniques, sources and time, but what researchers use is only two, namely the triangulation of techniques and sources. The process of analysing and interpreting data was carried out simultaneously when data collection in the field took place (Miles Huberman, 2010).

\section{Results and Discussion}

The results of the analysis conducted by researchers associated factors that affect the successful implementation of the Village Fund BLT for handling Covid-19 in the village in the district of West Kalimantan Selakau as follows:

\section{a. Communication between Actors in the Prevention Program Covid-19}

The Covid 19 pandemic prevention program includes rapid tests, distribution of masks carried out by the Selakau District Health Center with backups by Bhabinkamtibmas, Babinsa and District Kamtibmas Staff and village staff where the mask distribution activities were carried out. Various elements from the 3 pillars of government in the sub-district are backing up various government programs in preventing Covid in the regions. One of them is conducting joint raids, which are carried out for approximately 3 months from April to June 2020, namely by opening a Razia Post on the entrance road between districts or cities, namely raids on masks and body temperature, people who just returned from abroad that crossed or entered the sambas area. Synergy 
between public organizations in building understanding and togetherness with the efforts of various programs to support the success of the Covid 19 prevention program. There are no obstacles in the covid prevention program in carrying out the task of carrying out raids. In the early days there were many people who did not use masks, meaning that public awareness was still low.

During its development at that time, where the government made a "policy New Normal". This has led to a new phenomenon in the form of a perception in the community that the situation is normal or there is no Covid 19 pandemic outbreak. This makes activities in the community loser because conditions have returned to normal as before, so that people tend to neglect health protocols and perceive the virus. The Covid 19 pandemic is no longer there.

This fact, confirms that when the policies taken by the government in the formulation of their "use of the term" are not properly observed and are not effectively socialized to the public, it will lead to wrong understanding and various interpretations in the community regarding the policies that have been determined in their implementation.

The strategy carried out in Selakau District is to coordinate and communicate between the 3 pillars of the Muspika and staff in responding to the Covid-19 pandemic. One form of coordination and communication activities is the effort to prevent Covid-19 by spraying disinfectants together at various agencies and schools in the sub-district. The speed and accuracy in action of the public bureaucracy shows professionalism in program implementation, especially in relation to the value of responsibility in carrying out the main tasks and functions in implementing the program and maintaining that the program in its implementation can provide benefits, especially to the target group or target group of the program.

A form of activity in the prevention of Covid 19, where the head of the sub-district as the head of the Covid 19 sub-district control task force visits the villages or calls the village head to coordinate in implementing health protocols in his respective village environment. Other forms of activity, which were carried out by the subdistrict in implementing the Covid handling policy were limited to monitoring and urging villages to use village funds that were prioritized for the prevention and handling of Covid 19. This fact confirms the social communication strategy carried out by the sub-district bureaucracy by going directly to The ranks of the village government bureaucracy and village community members have implications for the growth of various forms of participation in the program. The same understanding of the objectives of a program from both the program implementing actors and the program target groups is the most important part of the successful implementation of a program.

The Covid 19 prevention program in Semalagi Besar village by spraying disinfectants into people's homes with 2 (two) stages of spraying activities. The spraying activity was initiated by the Singkawang City Government in collaboration with the Semalagi Besar Village Government. This is due to the geographical location of the village, which is directly adjacent to the city of Singkawang. What's more, in line with "the level of the spread of covid 19 in the city of Singkawang which continues to increase from time to time, even some time ago the Mayor of Singkawang Tjhai Chui Mie and a number of family members were recorded as positive for Covid 19 (Kompas.id. 4 September 2020). Then based on the latest data, there are a total of 30 Covid 19 patients in Singkawang City, 13 people are still being treated and 17 people are undergoing independent isolation. Kalbar.antara news.com. 26 September 2020).

This phenomenon shows the existence of mutually supportive bureaucratic behavior between the City Government of Singkawang and the Village Government of Semalagi Besar, and the emergence of networks between government actors without dividing government levels in implementing the COVID-19 pandemic prevention program. This confirms the existence of bureaucratic discretion in building cross-sector networks and between government agencies between city governments and village governments in the implementation of the COVID-19 pandemic prevention program. Thus, the implementation of programs in the form of preventing the spread of a pandemic has in fact created the same behaviour both for individual actors, institutions and levels of government and across governmental boundaries outside regional boundaries. and administrative authority of a government. This shows the spirit of actor collaboration in implementing the COVID-19 pandemic prevention program.

Strategies in the same understanding of all actors for the program, which are strengthened by the commitment and networks of all actors in building synergy that is displayed by the actors. This confirms a program implementation in overcoming pandemic or disaster-related problems that have a wide impact on society, by forming a common understanding of all actors, to build mutual commitment and synergy through the flexibility of the network structure of institutional actors in program implementation.

In addition, the village government and village officials with strategies, including making pamphlets or banners about the prevention and handling of the danger of the COVID-19 pandemic, which are placed or installed in the Village Office and the entrance of every hamlet in the village. Village government in Selakau District, including Semelagi Besar Village and Sungai Daun Village have issued a Decree of the Head of Semelagi Besar Village Number 14 of 2020 dated 27 March 2020 and Decree of the Village Head of Sungai 
Daun Number 20 of 2020 dated 16 April 2020 concerning the Task Force or Village Volunteers to Fight Covid 19.

Various activities The team of village volunteers against Covid 19 in implementing the Covid 19 pandemic prevention program includes spraying disinfectants, reporting or recording residents who come from abroad. make appeals to people who come from outside the city or abroad to report to the village and Puskesmas, as well as carry out independent isolation. Another thing, the village government is proactive with the puskesmas making efforts to pick up the ball for residents who have just come from abroad for data and health checks. The village government also limits the wedding ceremony activities to a maximum of 5:00 p.m. The custom of the saprahan, which is usually one stretch for 50 invited guests, is to be trimmed to 20 invited guests, while maintaining a maximum distance of 2 meters between one saprahan and another.

\section{b. Attitude of Implementing Actors in the Covid-19 Pandemic Management Program}

The Covid 19 pandemic prevention policy is mainly related to the preventive policies issued by the government, namely maintaining distance and preventing crowds (social distancing) which is very influential in activities of daily life, such as learning with the system online, working from home (WFH), lonely economic activities due to guard policies. distance. All that, until now, has continued, resulting in reduced human activity in various lives, affecting several sectors, especially the economy. This has resulted in termination of employment, disruption of the smooth running of small and micro businesses in the village, an increase in the number of poor people who were not previously categorized as poor.

Then in responding to these conditions the government has distributed various social assistance from the government in the form of $\mathrm{PKH}$, food cards and those previously programmed. by increasing the number of recipients, the nominal value and the period of receipt. Likewise, the provincial government provides assistance to the Governor of West Kalimantan in the form of rice assistance as much as $20 \mathrm{~kg}$ for poor families in each district. The same thing was done by the Sambas district government to provide assistance from the Regent of Sambas Regency in the form of $10 \mathrm{~kg}$ of rice, 2 litres of cooking oil which was distributed to all villages, based on data name by name from the West Kalimantan Provincial Government and from the Sambas Regency Government. The sub-district capacity only distributes Pemprov's social assistance directly to each village according to the number of quotas and according to the name originating from the province and monitors the implementation of the distribution. Assistance sourced from the provincial government in its implementation runs effectively.

Some of the social assistance for the prevention of Covid 19 also comes from the centre, namely the Ministry of Social Affairs, however, the fact that the implementation of this assistance program in the field has caused problems, with protests or claims from some members of the community because they did not get social assistance because they felt they deserved this assistance. . This is reinforced by the fact that people who are not affected by Covid 19 such as an ASN get it, which happens to be the wife of the village head. This also made the village head and his wife confused and asked why they got social assistance or the target group from the ministry's social assistance program.

This fact confirms the absence of synchronization of NIK data with data on social assistance recipients carried out by the Ministry of Social Affairs. This weakness in data management has created a sense of suspicion and conflict between fellow villagers, which in turn creates new social problems in the village, even though the fault lies in the data sources used by the government. This condition, if not properly explained and the contributing factors, will lead to public distrust of both individual and institutional actors involved in implementing the social assistance program.

Public distrust of actors in implementing programs, especially social assistance programs, has implications for distrust of the ruling regime, which in turn can lead to the efforts of certain groups of people with movements to bring down the regime or government in power unconstitutional. This, of course, is not expected because it will cause social instability and even lead to horizontal conflicts, which have occurred in this country.

In line with that, social assistance program implementing actors are needed to respond appropriately and quickly, especially by improving the data base overall from various sources towards the use of one Indonesian data (SDI), which must be started and implemented consistently by all actors in implementing the program so that it is appropriate. on target, on time and on budget.

This was then followed up by the village to verify the data again based on real and accurate reference data sources in the field. then return the incorrect name of the recipient of the social assistance to the Post Office by coordinating in advance with the sub-district and forwarding the report to the District Social Service. This shows that the implementation of the social assistance program is invalid and from reference data sources that are not updated at any time, thus affecting the village quota for the social assistance program from the government. The data source used by the ministry is based on integrated social welfare data (DTKS), which in fact data validation is still incomplete.

Apart from social assistance from the government, the West Kalimantan Provincial Government, there is also social assistance from the Sambas Regency Government. The same phenomenon also occurs with social 
assistance originating from the Sambas Regency Government, with complaints from villagers regarding the Covid 19 social assistance program. Even though the social assistance proposal mechanism originates from the village, then the proposals of potential recipients of social assistance from the village are forwarded to the subdistrict. The village sub-district proposal was forwarded to the Sambas Regency Social Service, to re-verify the proposal, and then determine the names of potential recipients of social assistance from the district government who passed the verification based on suggestions from each village.

This fact shows that the problem of village data validation on proposals from social assistance recipients was not valid when it was proposed to the sub-district to be forwarded to the district. This fact confirms that the problem of data validation is a fundamental problem that occurs, both at the village government level up to the government in implementing the social assistance program. The issue of data validation and the use of invalid or different data as the basis for providing social assistance, whether used by the government, provincial government, district government and village government, will cause problems of inaccurate program targeting and program utilization.

The follow-up to Presidential Regulation Number 39 of 2019 concerning One Indonesian Data should be of concern to the ranks of the government, local governments and sub-district / village governments to be applied consistently. Therefore, the implementation of the Indonesian One Data Policy (SDI) aims to promote the effectiveness of program implementation, which is carried out by program implementing actors and to avoid conflicts related to the inaccuracy of program targets in program implementation, especially programs that are social assistance.

The complaint mechanism against the social assistance program is related to handling the impact of the Covid 19 pandemic, including through a mechanism where villagers make complaints to village officials, then the complaint is followed up by village officials, then submitted to the sub-district. Subsequently, the sub-district conducted a sub-district deliberation involving elements from Bhabinkamtibmas, Babinsa, District staff, an integrated social welfare team (TKST), and sub-district assistants.

The results of deliberations at the sub-district level and actions that were decided upon in response to complaints from the community were then followed up by the District Team by holding a meeting at the village level. A meeting at the village level was held to provide explanations and responses to various complaints submitted by villagers, attended by the village head and village officials, the head of the BPD and its members, community leaders and villagers. This is done in an effort to get the same understanding of the problem or complaint submitted and an agreement on the action or action to be taken on the complaint.

\section{c. Resources in Handling Covid-19}

In responding to the impact of the Covid 19 pandemic, the government has provided opportunities to village governments that have made APBDesa in accordance with the instructions in Permendes No. 11 of 2019 before the outbreak of Covid-19, where village funds can be allocated for various activity programs such as cash for work, community empowerment, improving the quality of human resources, building Posyandu, and others to revise the Village Budget. The changes are only for two focuses, namely the first is for cash-intensive labor, and the second is for the prevention and handling of Covid-19.

The village government has a program in handling Covid 19, namely the BLT program at the village level funded by the Village Fund. BLT is received in cash. There were 116 people who received BLT in Semelagi Besar Village. The disbursement of BLT funds began in June 2020, which was carried out in several stages. The disbursement of stages 1 to 3 was carried out in June, July, August) each BLT recipient received Rp. 600,000, then continued with the disbursement of stages 4 to 6 , namely September, October and November, each BLT Desa recipient received Rp. . 300,000.

The village government, namely the Head of Village and Village Officials has implemented Permendes PDTT Number 6 of 2020 as an amendment to Permendes No. 11 of 2019. The contents of this Permendes, confirm that village funds can be used for BLT Village Funds. BLT which is sourced from village funds intended for the poor in villages in the midst of the Coronavirus outbreak. This shows a commitment from the Village Government to its residents affected by the Covid 19 pandemic and strong leadership from the Village Head and Village Officials, and the support of the Head of the BPD and its members and the Community in approving APBDes changes which are focused on villagers affected by the Covid 19 pandemic.

The total BLT Desa that was distributed to program beneficiaries was Rp. 2,700,000, with the distribution carried out in stages starting from June to November 2020. This fact indicates an increase in the amount of budget allocation made by the Pemdes. Whereas Abdul Halim Iskandar as the Minister of PDTT said "each family will get Rp. 600 thousand for three months, April, May and June until the total becomes Rp. 1.8 million "

The next development the Minister of PDTT issued Permendes No. 6 of 2020 is the second amendment to the PDTT Regulation No.11 of 2019 concerning the priority for the use of village funds in 2020 related to the extension of the Village Fund BLT for the next 3 months, starting in July, August and September. Then finally there is the latest regulation by the Ministry of PDTT to extend the Village Fund BLT program until December 2020 . 
The village government has carried out the Village BLT mandate aimed at the poor in villages affected by Covid-19 in the form of money. However, the implementation of BLT Village Fund disbursement to be given to recipients in non-cash or through bank transfers was not possible, due to the time-consuming account management process and the existence of financing for opening new account numbers, Village BLTs which are temporary and conditional in relation to handling the impact of Covid 19.

Situation Therefore, making the village government make a model for disbursement of the Village BLT to be carried out in cash and beneficiaries directly came to the village office in an interval of 2 (two) weeks for the disbursement process in each stage, then the next 2 weeks was empty, after which the disbursement was continued for the next stage and so on until it ends in the sixth stage in November 2020. This confirms that there is a clear schedule and time interval for disbursement during the Covid 19 pandemic, and can minimize the occurrence of crowds when compared to non-cash disbursements through accounts in banks that ignore health protocols.

In addition, payments made in cash by the village government are also a mechanism for monitoring the accuracy of the target group beneficiaries of the Village BLT program, who come from pre-prosperous families or are affected by the Covid pandemic 19. Innovations made by the Village Government in the process of disbursing Village BLT funds this is an effort to maintain accountability for program distribution, especially for the accuracy of the targeting of program beneficiaries.

The Village BLT program does not have assistance like the family hope program $(\mathrm{PKH})$ by local facilitators or sub-district facilitators. Because of the nature of the Village BLT program, the Village Government's responsiveness program in handling the impact of the Covid 19 pandemic, which is conditionally sourced from village funds with the target of the program being underprivileged people who are not registered in the government social assistance program and villagers directly affected by the Covid 19 pandemic.

The model for disbursement of the Village BLT budget which was carried out in cash and the collection was carried out at the village office, apart from being a form of assistance, it was also a form of supervision carried out by the Village Government towards the accuracy of targeting of BLT beneficiaries. This, as a social communication strategy in the implementation of programs carried out by the Village Government, especially in building synergy with program recipient residents in the utilization of this assistance and fostering participation of the target group towards the objectives of the implementation of the Village BLT program.

In addition, the amount of budget allocation received by the Village BLT, target group was greater, namely Rp. 2.7 million through 6 stages of disbursement over 6 months carried out by the village government which is different from the instruction of the Minister of PDDT which stipulates an allocation of Rp. 1.8 million through 3 stages of disbursement over 3 months. This shows the wisdom of the village government by considering the Covid 19 pandemic. It is hoped that during that time it will slope further and daily life and economic activities will return to normal while maintaining health protocols. These considerations are a form of thinking wisdom from field actors at the lowest levels of government, who exercise their authority in implementing programs with full consideration and reading the real conditions in the community.

The Village BLT program is aimed at people in the pre-prosperous category who are not registered in other social assistance programs such as PKH and food cards, and for villagers who have been directly affected by the Covid 19 pandemic economically. Furthermore, in order to maintain the accuracy of the Village BLT program targeting, it is carried out through field data collection that comes from below, namely data from the neighbourhood unit (RT) which is of course more up-to-date so that it will be more precise in its determination.

Support from village officials whose position is at the same time as village volunteers against Covid 19 and several other village volunteers, who collaborate with RT in conducting data collection on village residents directly, who meet the requirements to be considered as Village BLT recipients. This fact confirms the existence of synergistic efforts between program implementing actors to check and check data directly in the field, especially potential village BLT beneficiaries, to minimize the occurrence of conflicts of interest and the occurrence of complaints from villagers in determining beneficiaries of Village BLT program.

Various efforts have been made by the village government bureaucracy in supporting the success of the Covid 19 pandemic handling program. This is in accordance with the actual purpose of the formation of the government bureaucracy, namely: "To implement public services in a democratic manner, therefore all bureaucratic officials have an obligation to uphold and implement the principles of participation, equality of service, sensitivity and responsibility, all of which are manifestations of democracy in the ranks of the bureaucracy". (Yates, in Dwiyanto, 1991: 71). The process of determining the KK(family card) recipients of the Village BLT program is carried out with the involvement of the community through a team of village volunteers and the Head of the RT in capturing the right target group, to avoid mis-targeting, which is then verified and the allocation of the number of recipients and the amount of budget received by the target group is determined. through the discussion which is subsequently determined through a village head decree. All of that is a manifestation of the sensitivity and responsibility built by Pemdes actors as program implementers in realizing the benefits of programs that are right on target and do not cause conflicts in their implementation. 
In addition to the Village BLT, the village government has carried out PKTD activities with budget allocations sourced from village funds, including the construction of footpaths located in two hamlets using a community wholesale system. Someone who is responsible is the TPK (Activity Management Team) which consists of community leaders and RTs. The village assistant team is also involved in village development activities.

\section{d. Bureaucratic Structure in handling Covid-19}

The various bureaucratic activities implementing the Covid 19 prevention and handling program at the Selakau District level show that public organizations in providing services to the community as an organization with an open system that have developed themselves both internally and externally in carrying out their main tasks, as stated by Katz and Kahn, namely; "By developing various functions that carry work in a system, maintaining structure, fostering support from the environment, adapting to environmental changes following coordination and monitoring activities (in Harmon, 1996: 169).

The public bureaucratic structure developed with an open system opens wide opportunities for all parties to be involved in the formulation of goals and there is space in forming new institutions, new models or strategies that are more locally oriented, such as developing problem-solving systems based on the participation of all elements. , so that there are wider opportunities for engagement bottom-up and top-down balanced. This condition, of course, will make public organizations at the sub-district level always dynamic and sustainable in running their organizations in order to provide optimal public services at the sub-district level.

This shows the strength of the bureaucratic network in providing feedback in the form of solution actions. In addition, there is support for positive behaviour from actors to take quick response actions through coordination activities across sectors of actors through a deliberation mechanism among actors at various levels of government. This fact shows that there is an effort to build a network of actors in program implementation, by holding sub-district deliberations that involve elements of the Muspika, such as Babinsa, Babinkamtibmas, District Staff,, and District Facilitators.

In addition, the fast anticipatory attitude of actors or public bureaucracy involved in the program also shows that the public bureaucracy, which is involved in the sub-district task force team, is always on alert, in anticipating the phenomenon of errors in the management of social assistance to prevent Covid, in order to avoid conflicts between communities and beliefs low level of community members towards the government, especially the government at the sub-district level.

This bureaucratic solidity was not only when implementing various programs at the time of Covid 19, but this solidity was manifested by holding regular monthly meetings of various Muspika elements with the village government and village officials in Selakau District in the form of Coffee Morning which was carried out in an ongoing manner. take turns or take turns in each village in each month.

This fact, confirms with a social communication approach strategy with a simple face-to-face communication model and relationship between sub-district government agencies through the "Morning Coffee" activity together involving various Muspika elements with the Village Government, has given excitement or enthusiasm from various actors as well as public institutions in the success of development programs implemented at the village level, especially various social assistance programs related to the prevention and handling of the Covid 19 pandemic which originated from various levels of government.

In addition, the strategy or model that is simple and friendly through the activity of "coffee together across sectors and across villages" between Muspika and the village government, which is carried out consistently and moves places or villages every month, is able to realize the synergy of Muspika elements. and the Village Government in understanding the problems of the community and resolving them appropriately.

The use and development of a well-managed informal communication system at the level of government at the sub-district and village level will certainly support the implementation of more effective communication, by creating togetherness of all actors involved, both staff and member organizations, to think and be responsible for the success of the program.

Whether we realize it or not, mechanisms to ensure horizontal communication do not usually exist in an organizational design. It is possible that the organizational structure is made more oriented to the power and authority structures, which emphasize the relationship between levels of the organizational hierarchy. This fact will certainly have an impact on sectoral arrogance which considers the division or division and the organization to be the most powerful.

The symptom of sectoral arrogance has been addressed by implementing effective horizontal communication, at the level of governmental organizations in the sub-district by increasing solidarity between organizations in implementing the prevention and handling of Covid 19, as stated by Liliweri (1997: 297) "it must be supported by the principle of communication that relies on the solidarity or nursing to deal with major problems facing the organization in the form of integration of several parts, to ensure effective overall achievement.

In addition, the implementation of effective horizontal communication is very much needed in the 
implementation of programs that involve various organizational actors, in an effort to organize and integrate the various functions, which are carried out by each sub-district government organization in program implementation. This is done in an effort to collaborate with each other between organizations, to build coordination support from other organizations in achieving the objectives of the overall program.

The horizontal communication approach has been carried out by governmental organization actors at the sub-district level, in providing solutions related to various problems related to life in the community, such as some time ago the problem of gas scarcity that occurred in the community. This phenomenon is due to an indication of business play so that distribution does not pay attention to the priorities of the surrounding residents from the owners or gas bases in the sub-district amid the Covid 19 pandemic outbreak. the number of requests is not proportional. Failing to respond quickly and appropriately feared the gas scarcity issues, will add to the difficulties of society in the midst of a pandemic covid 19.

The fact that, addressed by Muspika for debate and find the best solution on the phenomenon at the Head Office, by calling the owner or manager of bases gas. This emphasizes how sub-district government agencies in implementing the Covid 19 pandemic prevention and handling program are trying to provide a solution to the scarcity of gas in the community, to prevent commotion and crowds queuing or fighting over the community to get gas to meet their daily needs. The problem of the scarcity of gas and commotion and a crowd of citizens queuing to get it, with the solution being taken by government agencies that some sub-districts aimed at maintaining social stability related to the scarcity of gas in the middle of a pandemic outbreak Covid 19.

Model sat with the three pillars of sub-districts, Koramil and police as well as the Village Government with the owners and managers of gas bases in the sub-district, in overcoming the problem of gas scarcity that occurred in the midst of the Covid 19 pandemic. Mutual understanding is needed to find the best solution and mutual agreement, by prioritizing people in the village or surrounding residents. where the base is. If the agreement is not followed up by the base, then Muspika will ask the relevant Dinas to impose sanctions or revoke the base's license and give the village an opportunity to establish a gas base as an alternative to the Bumdes business.

The responsiveness of Muspika and Pemdes in overcoming public problems in the midst of the Covid 19 pandemic through quick and correct decision making. This emphasizes the solidarity of actors through networking between actors and solidarity with public organizations through mutual understanding to solve problems faced by citizens in the midst of the Covid 19 pandemic. This will foster public trust in public organizations as actors in various prevention programs. and the handling of Covid 19 both at the sub-district and village levels which in turn will also affect the success of program implementation.

\section{Conclusion}

Based on the results of the discussion of previous research, it can be some conclusions as follows:

Communication among actors, each actor puts the interests together for the sake of success in handling covid-19, an actor also lowered his ego respectively for a more important purpose, namely handling covid and its impact on society. An understanding of the tasks that are carried out between agencies in handling Covid-19 in Selakau District has resulted in extraordinary synergy in the success of handling Covid-19. Synergy is also shown by the mutually supportive bureaucratic behaviour between the Singkawang City Government and the Semalagi Besar Village Government in Sambas Regency to handle Covid-19 jointly.

Attitudes shown by actors / implementers in handling novid-19 in Selakau District The Covid 19 pandemic prevention policy is very good in responding to various policies set by the central government. This is evidenced by the readiness of government officials involved in this. The handling of covid-19, including the formation of a Covid-19 Task Force Team at the District Level as well as at the Village level, the distribution of direct cash assistance (BLT) that comes from the centre or comes from. Village Funds to the affected community in accordance with predetermined rules and time. Complaints from the public that are quickly responded to or resolved, especially related to data on BLT recipients, with the attitude of the implementers will raise public confidence in the implementation of the Covid-10 prevention policy which will ultimately support the success of the program.

Resources to support success in. The handling of the Covid-19 pandemic at the District and Village levels is very adequate, this is indicated by the formation of a Task Force Team at the District and Village Levels when viewed from the side of financial resources, the government has issued various regulations to support the success of this program including the issuance of Permendes N0 11 of 2019 concerning Priority for the Use of Village Funds which provides opportunities for village governments that have made changes to the Village Budget. The changes are only for two focuses, namely the first is for cash-intensive labor, and the second is for the prevention and handling of Covid-19, which starts in July, August and September. The next development PDTT Minister issued Permendes No. 7 of 2020 regarding the Village Fund BLT for the next 3 months, extending the Village Fund BLT program until December 2020.

The bureaucratic structure applied in handling Covid-19 in Selakau District takes an open bureaucratic structure model, meaning this model provide wide opportunities for all parties to be involved in the formulation 
of goals and there is space in forming new institutions, new models or strategies that are more locally oriented, such as developing problem-solving systems based on the participation of all elements, so that wider opportunities are opened for engagement bottom-up and top-down balanced. This shows the strength of the bureaucratic network in providing feedback in the form of solution action, quick response action through coordination activities across sectors of actors through a deliberation mechanism among actors at various levels of government.

\section{References}

Books :

Abdul Wahab, Solichin. 1997. Analisis Kebijakan- Dari Formulasi Ke Implementasi Kebijakan Negara, Bumi Aksara, Jakarta

Agustino Leo, 2020, Analisis Kebijakan Penanganan Wabah Covid-19: Pengalaman, Indonesia, Jurnal Borneo Administrator, Volume 16, No. 02. LAN Samarinda.

Agustino, Leo, 2008. Politik \& Kebijakan Publik, Bandung: AIPI dan Puslit KP2W Lemlit Unpad

Badjuri H. Abdul Kahar, dan Yuwono, Teguh, 2002. Kebijakan Publik Konsep \& Strategi, Semarang: Universitas Diponegoro

Carolie, Bryant dan White, Louise G., Manajemen Pembangunan Untuk Negara Berkembang, Terjemahan Rusyanto, LP3ES, Jakarta, 1987.

Dye, Thomas R. 1978. Understanding Public Policy. Prentice Hall, Englewood Cliffs, N.J.

Dwiyanto, Agus., Birokrasi Di Indonesia, Konsep, Citra dan Reformasi, Laporan Penelitian, Fisipol UGM, Yogyakarta, 1991.

-------, Penilaian Kinerja Organisasi Pelayanan Publik, Makalah dalam Seminar Kinerja Organisasi sektor Publik, Kebijakan dan Penerapannya, Fisipol UGM, Yogyakarta, 1995.

Darwin, Muhadjir, Demokratisasi Birokrasi Di Indonesia, dalam Demokrasi Indonesia Kontemporer, Editor Riza Noer Arfani, PT. Raja Grafindo Persada, Jakarta, 1996.

Effendi, Sofian, Dkk, Alternatif Kebijaksanaan Perencanaan administrasi; Suatu Analisis Restrospektif dan Prospektif, Seri Monograf, Fisipol UGM, Yogyakarta, 1989.

Edward III, George, C., Implementing Public Policy, Congressional Quarterly Press, Washington, DC, 1980.

Handoko, Hani T., Manajemen, Edisi 2, Cetakan ke 12, BPFE, Yogyakarta, 1997.

Harmon, Michael M. dan Mayer, Richard T., Organization Theory For Public Administrations, Little Brown and Company, Boston, Toronto, 1986.

Ivancevich, John M.,et.hall., Organisasi Dan Manajemen, Prilaku, Struktur dan Proses, Cetakan ke 4, Erlangga, 1988.

Islamy, M. Irpan, 2001. Prinsip-Prinsip Perumusan Kebijaksanaan Negara, Jakarta: Bumi Aksara

Kumorotomo, Wahyudi, Profil Desa Tertinggal, Bappenas, Jakarta, 1992.

-------, Etika Administrasi Negara, Rajawali Pers, Jakarta, 1992.

Leonard, David K., dan Marshall, Dale Rogers., Eds, Institutions of Rural Development for The Poor, Barkely, California, Institute of International Studies, university of California, 1982.

Liliweri, Alo, Sosiologi Organisasi, PT. Citra Aditya Bhakti, Bandung, 1997.

Nugroho, Riant D. 2004. Kebijakan Publik : Formulasi, Implementasi, dan Evaluasi, Yakarta: Elex Media Komputindo

... , 2008. Publik Policy, Jakarta: Elex Media Komputindo

Ndraha, 2005. Teori Budaya Organisasi, Jakarta: Rineke

Putra, Fadillah, 2001. Paradigma Kritis Dalam Studi Kebijakan Publik, Yogyakarta: Pustaka Pelajar Offset

Ripley, Rendall B. dan Franklin Grace A., Policy Implementation and Bureaucracy, Second Edition, The Dorsey Press, Chicago, lllionis, 1987.

Steers, Richard M. Efektivitas Organisasi, Erlangga, Cetakan Ke Dua, Jakarta, 1985.

Strauss, Anselm., dan Juliet Corbin. 2003. Dasar-Dasar Penelitian Kualitatif, Yogyakarta: Pustaka Pelajar.

Sarosa, Samiaji. 2012. Penelitian Kualitatif: Dasar-Dasar. Jakarta: Indeks.

Subarsono, AG. 2011. Analisis Kebijakan Publik: Konsep, Teori dan Aplikasi. Yogyakarta: PustakaPelajar.

Suryabrata, Sumadi. 2012. Metodologi Penelitian. Jakarta; Rajawali Pers.

Tachjan, 2006. Implementasi Kebijakan Publik,Bandung: AIPI

Wahab, Abdul Solichin, 2005. Analisis Kebijaksanaan, Jakarta: Bumi Aksara

Walean, Lengkong dan Y. Londa, 2020, Implementasi Kebijakan Penanganan Covid 19 Di Desa Sea Tumpengan Kecamatan Pineleng Kabupaten Minahasa, Jurnal Administrasi Publik, Vol 06. No 96 Unsrat.

Winarno, Budi, 2005. Teori dan Proses Kebijakan Publik, Yogyakarta: Med Press.

\section{Other References :}


Undang-Undang Nomor 6 Tahun 2014 Tentang Desa

Peraturan Pemerintah Nomor 60 tahun 2014, yang selanjutnya disempurnakan melalui Peraturan Pemerintah Nomor 22 Tahun 2015 Tentang Dana Desa

Permendesa Nomor 19 Tahun 2017 Tentang prioritas penggunaan dana desa

Peraturan Bupati Kubu Raya Nomor 16 Tahun 2015 Tentang Tata Cara Pembagian dan Penetapan rincian Dana Desa Setiap Desa Kabupaten Kubu Raya

Mutia Fauzia. Kompas.Com. 26 Maret 2020. Selain Masyarakat Miskin, BLT dialokasikan untuk Driver Ojol dan Pegawai Mall.

------. Kompas.Com. 24 Maret 2020. Pemerintah Susun Skema untuk pemberian BLT bagi pekerja Harian dan $U K M$.

lensakalbar.co.id. Headline. 27 Maret 2020. Dampak Sosial Covid-19. Gubernur Minta Perusahaan Salurkan Sembako untuk Warganya.

Setkab.go.id. Humas. 31 Maret 2020. Keterangan Pers Presiden RI Mengenai Program Perlindungan Sosial Menghadapi Dampak Pandemi Covid-19

CNN Indonesia. 3 April 2020. Kalbar Potong Dana Perjalanan Dinas Bantu Warga Beli Beras.

m.detik.com.detik.news. 14 April 2020. Tiara Aliyah. Semangat Penggunaan BLT Dana Desa Harus Sesuai Amanat Presiden Jokowi.

m.detik.com. detikfinance.17 April 2020. Faidah Umu Sofuroh. Dimulai April, BLT Dana Desa Dikucurkan dalam 3 Tahap 